\title{
PENGARUH MODEL PEMBELAJARAN TEAM GAMES TOURNAMENT DAN TEAM ASSISTED INDIVIDUALIZATION DISERTAI DENGAN KEY RELATION CHART DITINJAU DARI MOTIVASI BELAJAR TERHADAP PRESTASI BELAJAR SISWA MATERI POKOK KOLOID KELAS XI IPA SMA NEGERI KEBAKKRAMAT TAHUN PELAJARAN 2015/2016
}

\author{
Charisma Nurwiyono Putri, Mohammad Masykuri ${ }^{*}$, dan Widiastuti A E S \\ Program Studi Pendidikan Kimia, FKIP,Universitas Sebelas Maret, Surakarta, Indonesia
}

*Keperluan korespondensi, telp: 08121500634, email: mmasykuri@yahoo.com

\begin{abstract}
ABSTRAK
Penelitian ini bertujuan untuk mengetahui: (1) pengaruh penggunaan model pembelajaran Team Games Tournament (TGT) dan Team Assisted Individualization (TAI) menggunakan media Key Relation-Chart (KR-Chart) terhadap prestasi belajar siswa; (2) pengaruh motivasi belajar (tinggi, sedang, rendah) siswa terhadap prestasi belajar siswa; (3) interaksi antara penerapan model TGT disertai KR-Chart dan model TAl disertai KR-Chart dengan motivasi belajar siswa terhadap prestasi belajar siswa pada materi pokok koloid. Penelitian ini merupakan penelitian eksperimen dengan desain faktorial $3 \times 3$. Populasi penelitian adalah siswa kelas XI IPA SMA Negeri Kebakkramat tahun pelajaran 2015/2016. Teknik pengambilan sampel dengan cluster rundom sampling. Analisis data menggunakan uji anava dua jalan dan uji Kruskal-Wallis dengan taraf signifikansi $5 \%(\alpha=0,05)$. Dari hasil penelitian diperoleh kesimpulan: 1$)$ terdapat pengaruh penggunaan model pembelajaran TGT disertai KR-Chart, TAI disertai KR-Chart, dan konvensional terhadap prestasi belajar kimia pada ranah kognitif, namun tidak terdapat pengaruh terhadap prestasi belajar siswa ranah afektif; 2) terdapat pengaruh motivasi belajar siswa pada pembelajaran materi koloid terhadap prestasi belajar kimia; 3) tidak ada interaksi antara penerapan model TGT disertai KR-Chart, model TAI disertai KR-Chart, dan konvensional dengan motivasi belajar siswa pada pembelajaran materi koloid terhadap prestasi belajar kimia.
\end{abstract}

Kata kunci: model TGT, model TAI, KR-Chart, motivasi belajar, koloid

\section{PENDAHULUAN}

Negara yang maju bukanlah negara yang hanya kaya akan hasil alamnya tetapi juga yang unggul kualitas manusianya. Kekayaan alam Indonesia yang melimpah apabila tidak diimbangi dengan sumber daya manusia yang unggul maka tidak akan berarti apa-apa. Oleh karena itu, pembangunan sumber daya manusia (SDM) berkualitas merupakan suatu keniscayaan yang tidak dapat ditawar lagi. Semakin pesatnya perkembangan iptek maka dituntut pula penyesuaian visi, misi, tujuan, dan strateginya agar sesuai dengan kebutuhan serta tidak ketinggalan zaman. Penyesuaian inipun terjadi pula pada sistem pendidikan yang bersifat mendasar. Untuk melaksanakan perubahan dalam bidang pendidikan tersebut sejak tahun 1998, UNESCO telah mengemukakan dua basis landasan, yaitu: 1) pendidikan harus diletakkan pada empat pilar yaitu belajar mengetahui (learning to know), belajar melakukan (learning to do), belajar hidup dalam kebersamaan (learning to live together), dan belajar menjadi diri sendiri (learning to be); 2)belajar seumur hidup (live long learning) [1].

Salah satu penyesuaian bidang pendidikan yang dilakukan oleh negara Indonesia adalah dengan menerapkan 
Kurikulum Tingkat Satuan Pendidikan (KTSP). Dalam kurikulum tersebut, kimia adalah salah satu mata pelajaran yang ada ditingkat SMA. Kimia merupakan salah satu pelajaran IPA yang pada hakekatnya merupakan pengetahuan yang berdasarkan fakta, hasil pemikiran dan produk hasil penelitian yang dilakukan para ahli, sehingga untuk kemudian perkembangan ilmu kimia diarahkan pada produk ilmiah, metode ilmiah dan sikap ilmiah.

Koloid merupakan salah satu materi dalam mata pelajaran kimia ditingkat SMA. Materi ini membutuhkan daya hafal dan pemahaman yang cukup, karena siswa akan mulai mempelajari jenis-jenis koloid, sifat-sifat koloid, dan pembuatan sistem koloid. Materi koloid sangat erat hubungannya dengan kehidupan sehari-hari. Penerapan sifatsifat koloid banyak kita jumpai dalam bidang industri, pertanian, maupun kedokteran, sehingga materi koloid menjadi sangat penting untuk dipelajari dan dipahami, bukan hanya sekedar untuk dihafalkan. Namun pentingnya materi sistem koloid ini tidak banyak disadari oleh pendidik (guru). Guru menganggap bahwa materi koloid tidak ada kaitannya dengan cabang-cabang ilmu kimia yang lain. Bentuk materi yang hanya berupa hafalan, membuat guru beranggapan bahwa siswa mampu mempelajarinya sendiri di rumah.

Sesuatu yang tidak dapat dipisahkan dari kegiatan belajarmengajar adalah prestasi belajar. Prestasi belajar siswa dipengaruhi oleh faktor internal,faktor eksternal dan faktor pendekatan belajar. Faktor internal merupakan faktor yang berasal dari dalam diri siswa meliputi dua aspek, yakni aspek fisiologis dan aspek psikologis. Faktor eksternal merupakan faktor yang berasal dari luar siswa yang meliputi dua aspek, yakni lingkungan sosial dan lingkungan non sosial. Faktor pendekatan belajar adalah segala upaya yang meliputi strategi dan metode yang digunakan siswa untuk melakukan kegiatan pembelajaran materi-materi pelajaran. Untuk mencapai hasil optimal, maka faktor-faktor tersebut perlu diupayakan dengan sebaik-baiknya [2].
Motivasi belajar merupakan salah satu faktor internal yang dapat mempengaruhi prestasi belajar. Karena dengan adanya motivasi tersebut akan menggerakkan siswa untuk selalu berusaha aktif dan melibatkan diri dalam kegiatan belajar mengajar. Semakin sering seorang siswa melibatkan dirinya dalam pembelajaran maka akan memiliki pemahaman yang lebih baik pula, sehingga siswa yang mempunyai motivasi belajar tinggi akan memiliki prestasi belajar yang lebih tinggi daripada siswa yang memiliki motivasi belajar yang rendah.

Menurut wawancara yang dilakukan dengan salah satu guru kimia SMA Negeri Kebakkramat, dalam kegiatan pembelajaran motivasi belajar siswa dirasa masih kurang optimal. Hal tersebut ditunjukkan dengan siswa kurang berperan aktif serta kerjasama antar siswa yang dapat menunjang tercapainya tujuan pembelajaran masih rendah. Siswa cenderung sibuk mencatat dan mendengarkan penjelasan dari guru saja, tanpa ada interaksi dengan siswa lain sehingga membuat pemahaman terhadap konsep-konsep kimia kurang mendalam. Dalam proses belajar mengajar guru lebih sering hanya menggunakan buku sebagai media pembelajarannya. Oleh karena itu dengan model pembelajaran yang kurang bervariasi, kurangnya aktifitas kelompok, serta kurangnya implementasi media pembelajaran dalam proses belajar mengajar, siswa seringkali jenuh dengan pembelajaran yang monoton yaitu hanya dengan mendengar dan melihat guru menjelaskan.

Salah satu cara untuk mengembangkan kompetensi siswa dalam kerja sama adalah melalui penggunaan model pembelajaran kooperatif. Model pembelajaran kooperatif dapat meningkatkan motivasi belajar siswa karena dengan berbagai model yang ada, guru dapat menggunakannya sebagai variasi pembelajaran, sehingga prestasi belajar siswapun juga akan mengalami peningkatan. Di dalam satu kelompok siswa yang berkemampuan tinggi akan membantu proses pemahaman bagi siswa yang berkemampuan rendah dan 
siswa yang berkemampuan sedang dapat menyesuaikan selama proses belajar berlangsung. Diharapkan kegiatan belajar mengajar tidak lagi didominasi oleh guru (teacher centered), akan tetapi lebih menempatkan siswa sebagai subyek didik, sehingga menuntut diterapkannya penggunaan model pembelajaran yang betpusat pada siswa (student centered) [3].

Upaya yang dapat ditempuh dalam pembelajaran yang terpusat pada siswa adalah dengan cara guru berperan sebagai fasilitator yang berfungsi sebagai jembatan penghubung ke arah pemahaman yang lebih tinggi. Model pembelajaran kooperatif yang digunakan adalah model pembelajaran Team Games Tournament (TGT) dan Team Assisted Individualization (TAI). Belajar sambil bermain tidak selalu berakibat pada rendahnya prestasi belajar siswa. Penyajian materi yang melibatkan siswa aktif dalam pembelajaran dan bermain bersama kelompoknya diharapkan mampu memberikan kontribusi pada peningkatan prestasi belajar siswa. Dengan diterapkan model pembelajaran kooperatif metode TGT yang desertai media, diharapkan siswa lebih semangat dalam mempelajari materi pokok koloid. Model Team Assisted Individualization (TAI) merupakan salah satu model pembelajaran dengan menggunakan teman sejawat sebagai asisten saat proses pembelajaran. Peserta didik yang awalnya tidak berani bertanya dengan guru saat proses pembelajaran yang berpusat pada guru, maka dengan menggunakan TAl peserta didik akan lebih berani untuk bertanya kepada asisten yang merupakan temannya sendiri, sehingga keingintahuan merekapun akan semakin muncul dan diharapkan kesulitan-kesulitan yang dialami oleh peserta didik terkait dengan materi akan dapat teratasi.

Dalam penerapannya pada proses pembelajaran, model pembelajaran kooperatif tipe TGT dan TAl ini dapat ditunjang dengan berbagai media pembelajaran. Kurangnya implementasi media pembelajaran seperti hanya digunakannya buku sebagai media, menyebabkan siswa merasa jenuh.
Siswa dituntut untuk terlalu banyak memahami penjelasan dari suatu materi, sehingga siswa sering merasa berat dan bosan untuk memahami lebih dalam. Adapun salah satu media pembelajaran cetak yang dapat digunakan untuk mengatasi banyaknya konsep dengan cara meringkasnya yaitu berupa Key Relation Chart atau KR-Chart. Key Relation Chart merupakan lembaran yang berisi hubungan tentang fakta, konsep dan prinsip yang penting dari suatu materi pelajaran [4]. Penggunaan KR-Chart dipilih karena dalam materi koloid memuat banyak konsep, fakta dan prinsip dimana KR-Chart ini dapat mempermudah siswa untuk menghubungkan antar konsep.

Berdasarkan latar belakang yang telah diuraikan diatas penulis merasa perlu untuk melakukan penelitian tentang pengaruh model pembelajaran Team Games Tournament (TGT) dan Team Assited Individualization (TAl) disertai dengan Key Relation Chart terhadap prestasi belajar siswa materi pokok koloid kelas XI IPA SMA Negeri Kebakkramat tahun pelajaran 2015/2016.

\section{METODE PENELITIAN}

Penelitian ini dilaksanakan di SMA Negeri Kebakkramat pada kelas XI IPA Semester Genap Tahun Pelajaran 2015/2016. Metode penelitian yang digunakan adalah metode eksperimen dengan desain faktorial $3 \times 3$. Adapun bagan desain penelitian disajikan pada Tabel 1.

Tabel 1. Desain Penelitian Faktorial 3x3

\begin{tabular}{|c|c|c|c|}
\hline \multirow{2}{*}{$\begin{array}{c}\text { Model } \\
\text { Pembela- } \\
\text { jaran }\end{array}$} & \multicolumn{3}{|c|}{ Motivasi Belajar } \\
\hline & $\begin{array}{c}\text { Tinggi } \\
\left(\mathrm{B}_{1}\right)\end{array}$ & $\begin{array}{l}\text { Sedang } \\
\left(\mathrm{B}_{2}\right)\end{array}$ & $\begin{array}{c}\text { Rendah } \\
\left(\mathrm{B}_{3}\right)\end{array}$ \\
\hline $\begin{array}{c}\text { TGT } \\
\text { disertai } \\
\text { KR-Chart } \\
\left(\mathrm{A}_{1}\right) \\
\mathrm{TAl}\end{array}$ & $A_{1} B_{1}$ & $A_{1} B_{2}$ & $\mathrm{~A}_{1} \mathrm{~B}_{3}$ \\
\hline $\begin{array}{c}\text { disertai } \\
\text { KR-Chart } \\
\left(\mathrm{A}_{2}\right) \\
\text { Kelas }\end{array}$ & $A_{2} B_{1}$ & $A_{2} B_{2}$ & $\mathrm{~A}_{2} \mathrm{~B}_{3}$ \\
\hline $\begin{array}{c}\text { kontrol } \\
\left(\mathrm{A}_{3}\right)\end{array}$ & $A_{3} B_{1}$ & $A_{3} B_{2}$ & $A_{3} B_{3}$ \\
\hline
\end{tabular}


Penelitian dilaksanakan dari bulan Januari sampai Oktober 2016 dengan subjek penelitian siswa kelas XI IPA 1, XI IPA 3, dan XI IPA 4 diperoleh dari teknik cluster rundom sampling. Ketiga kelas sampel sebelumnya telah dilakukan uji normalitas, homogenitas, dan keseimbangan. Hasil uji menunjukkan bahwa ketiga kelas tersebut mempunyai kemampuan yang sama. Kelas XI IPA 1 (kelas eksperimen I) diberikan perlakuan model TGT disertai KR-Chart, kelas XI IPA 4 (kelas eksperimen II) diberikan perlakuan model TAl disertai KR-Chart, dan kelas XI IPA 3 (kelas kontrol) diberikan perlakuan model konvensional.

\section{HASIL DAN PEMBAHASAN}

Sebelum diberikan perlakuan model pembelajaran TGT dilengkapi KRChart, TAl dilengkapi KR-Chart, dan konvensional ketiga kelas diberi angket motivasi belajar untuk mengetahui motivasi belajar siswa. Motivasi belajar siswa dikategorikan menjadi tinggi, sedang, dan rendah. Data mengenai jumlah siswa yang memiliki motivasi belajar tinggi, sedang, rendah disajikan pada Tabel 2.

Data dari penelitian ini adalah nilai motivasi siswa dan prestasi belajar siswa pada materi koloid yang meliputi ranah kognitif dan ranah afektif. Data tersebut dirangkum dalam Tabel 3 dan Tabel 4.

\section{Pengujian Hipotesis}

Pengujian hipotesis dilakukan menggunakan analisis variansi (ANAVA) dua jalan dengan desain faktorial $3 \times 3$. Sebelum dilakukan uji ANAVA, terdapat beberapa persyaratan analisis yang harus dipenuhi yaitu uji normalitas dan uji homogenitas variansi. Kedua uji tersebut dilakukan dengan menggunakan bantuan IBM SPSS v.18. Berdasarkan uji normalitas menggunakan uji ShapiroWilk diperoleh hasil bahwa data prestasi belajar ranah kognitif dan afektif berdistribusi normal. Berdasarkan uji homogenitas menggunakan uji Levene Statistic diperoleh hasil bahwa pada prestasi belajar ranah kognitif homogen, namun pada ranah afektif tidak homogen sehingga analisis data menggunakan Kruskal-Wallis.

\section{a. Hipotesis Pertama}

Berdasarkan hasil pengujian anava dua jalan pada ranah kognitif dari ketiga model pembelajaran yang diterapkan menunjukkan bahwa nilai Sig. $(0,00)<\alpha$ $(0,05)$ sehingga $H_{0 A}$ ditolak dan $H_{1 A}$ diterima. Dapat disimpulkan bahwa terdapat pengaruh model pembelajaran kooperatif TGT disertai KR-Chart (kelas eksperimen I), TAI disertai KR-Chart (kelas eksperimen II), dan konvensional terhadap prestasi belajar ranah kognitif siswa pada pokok bahasan sistem koloid. Besarnya rataan nilai prestasi belajar ranah kognitif kelas TGT adalah 70,78 , kelas TAl adalah 68,73, dan kelas konvensional 58,23.

Tabel 2. Frekuensi Motivasi Belajar Siswa

\begin{tabular}{ccccccc}
\hline \multirow{2}{*}{$\begin{array}{c}\text { Motivasi } \\
\text { Belajar }\end{array}$} & \multicolumn{2}{c}{ TGT dengan KR-Chart } & \multicolumn{2}{c}{ TAl dengan KR-Chart } & \multicolumn{2}{c}{ Konvensional } \\
\cline { 2 - 7 } & $\begin{array}{c}\text { Fre } \\
\text { kuensi }\end{array}$ & $\begin{array}{c}\text { Persen } \\
\text { tase }(\%)\end{array}$ & $\begin{array}{c}\text { Fre } \\
\text { kuensi }\end{array}$ & $\begin{array}{c}\text { Persen } \\
\text { tase }(\%)\end{array}$ & $\begin{array}{c}\text { Fre } \\
\text { Kuensi }\end{array}$ & $\begin{array}{c}\text { Persen } \\
\text { tase }(\%)\end{array}$ \\
\hline Tinggi & 3 & 8,33 & 6 & 16,67 & 4 & 11,11 \\
Sedang & 28 & 77,78 & 21 & 58,33 & 29 & 80,56 \\
Rendah & 5 & 13,89 & 9 & 25 & 3 & 8,33 \\
\hline Jumlah & 36 & 100 & 36 & 100 & 36 & 100 \\
\hline
\end{tabular}

Tabel 3. Rangkuman Deskripsi Data Penilaian

\begin{tabular}{cccc}
\hline \multirow{2}{*}{ Jenis Penilaian } & \multicolumn{3}{c}{ Nilai Rata-Rata } \\
\cline { 2 - 4 } & TGT dilengkapi KR- & TAI dilengkapi KR- & Konvensional \\
\hline Nilai Kognitif & 70,78 & Chart & 58,23 \\
Nilai Afektif & 73,03 & 68,73 & 71,77 \\
\hline
\end{tabular}


Tabel 4. Prestasi Belajar Ranah Kognitif dan Ranah Afektif Berdasarkan Kemampuan Memori Siswa

\begin{tabular}{ccccccc}
\hline & \multicolumn{3}{c}{ Ranah Kognitif } & \multicolumn{3}{c}{ Ranah Afektif } \\
\cline { 2 - 7 } Model Pembelajaran & \multicolumn{3}{c}{ Motivasi Belajar } & \multicolumn{3}{c}{ Motivasi Belajar } \\
\cline { 2 - 7 } & $\begin{array}{c}\text { Tinggi } \\
\left(\mathrm{B}_{1}\right)\end{array}$ & $\begin{array}{c}\text { Sedang } \\
\left(\mathrm{B}_{2}\right)\end{array}$ & $\begin{array}{c}\text { Rendah } \\
\left(\mathrm{B}_{3}\right)\end{array}$ & $\begin{array}{c}\text { Tinggi } \\
\left(\mathrm{B}_{1}\right)\end{array}$ & $\begin{array}{c}\text { Sedang } \\
\left(\mathrm{B}_{2}\right)\end{array}$ & $\begin{array}{c}\text { Rendah } \\
\left(\mathrm{B}_{3}\right)\end{array}$ \\
\hline TGT dilengkapi KR- \\
$\quad$ Chart $\left(\mathrm{A}_{1}\right)$ & 88,88 & 70,63 & 60,74 & 84,99 & 73,48 & 63,33 \\
TAl dilengkapi KR- & & & & & & \\
$\quad$ Chart $\left(\mathrm{A}_{2}\right)$ & 84,57 & 69,66 & 55,97 & 86,53 & 74,48 & 71,85 \\
Konvensional $\left(\mathrm{A}_{3}\right)$ & 68,51 & 58,11 & 45,58 & 82,29 & 70,70 & 68,06 \\
\hline
\end{tabular}

Berdasarkan perhitugan Multiple Comparrasons, perbedaan pengaruh yang signifikan terdapat pada kelas yang diberikan model pembelajaran TGT disertai KR-Chart dengan model konvensional serta pada kelas dengan model TAl disertai KR-Chart dengan model konvensional. Sedangkan pada kelas dengan model TGT disertai KRChart dengan TAI disertai KR-Chart tidak terdapat perbedaan yang signifikan. Hal ini menunjukkan bahwa kedua model yang diberikan akan memberikan perubahan yang signifikan terhadap prestasi belajar siswa jika dibandingkan dengan model konvensional.

Berdasarkan hasil penelitian didapatkan bahwa nilai rata-rata siswa yang diberikan pembelajaran dengan model TGT disertai KR-Chart lebih tinggi dari pada rata-rata siswa yang diberikan pembelajaran dengan model TAI disertai KR-Chart dan lebih tinggi dari rata-rata siswa yang diberikan pembelajaran dengan model konvensional. Hal tersebut sesuai dengan penelitian sebelumnya yang menyatakan bahwa penggunaan model pembalajaran TGT lebih baik. Hal ini dikarenakan pada model pembelajaran TGT terdapat turnamen yang menekankan pada kerjasama kelompok serta keaktifan siswa dalam mencari jawaban sendiri dengan cepat sehingga siswa harus mempunyai pengetahuan yang cukup untuk bermain.

Hasil dari pengujian Kruskal-Wallis pada ranah afektif dari ketiga model pembelajaran yang diterapkan menunjukkan bahwa nilai Asymp.Sig $(0,127)>\alpha(0,05)$. Dapat disimpulkan bahwa tidak terdapat pengaruh model pembelajaran kooperatif TGT disertai
KR-Chart (kelas eksperimen I), TAI disertai KR-Chart (kelas eksperimen II), maupun konvensional terhadap prestasi belajar ranah afektif siswa pada materi sistem koloid. Besarnya rataan nilai prestasi belajar ranah afektif siswa yang diajar dengan menggunakan model TGT disertai KR-Chart adalah 73,03, yang menggunakan model TAl disertai KRChart adalah 75,83, dan yang menggunakan model konvensional adalah 71,77 .

Tidak adanya pengaruh model pembelajaran terhadap prestasi belajar ranah afektif siswa karena prestasi belajar ranah afektif siswa lebih dipengaruhi oleh faktor internal yang ada dalam diri siswa. Model pembelajaran bukan sebagai faktor penting pendorong sikap siswa, akan tetapi karakteristik siswalah yang mempengaruhi sikap siswa [5].

\section{b. Hipotesis Kedua}

Hasil dari pengujian anava dua jalan pada ranah kognitif maupun hasil pengujian Kruskal-Wallis pada ranah afektif, jika dilihat dari motivasi belajar siswa menunjukkan bahwa nilai Sig. $(0,00)<\alpha(0,05)$, maka $\mathrm{H}_{\mathrm{OB}}$ ditolak dan $\mathrm{H}_{1 \mathrm{~B}}$ diterima. Dapat disimpulkan bahwa terdapat pengaruh motivasi belajar siswa terhadap prestasi belajar ranah kognitif maupun afektif siswa pada pokok bahasan sistem koloid. Oleh karena itu pada hipoteisis kedua ini perlu dilakukan uji lanjut dengan menggunakan uji komparasi ganda. Hasil uji lanjut terhadap hipotesis kedua yaitu motivasi belajar tinggi, sedang, rendah baik pada ranah kognitif maupun ranah afektif menunjukkan bahwa setiap kategori 
sama-sama memiliki pengaruh yang signifikan terhadap prestasi belajar.

Pada materi sistem koloid, motivasi belajar siswa diperlukan untuk mendorong siswa agar lebih aktif dalam proses pembelajaran. Motivasi belajar yang memadahi akan mendorong siswa berperilaku aktif untuk berprestasi dalam kelas.

Motivasi sebagai keterlibatan akademis mengacu pada ranah kognitif, emosional, dan indikator perilaku siswa. Motivasi berprestasi memberikan kontribusi positif terhadap nilai siswa pada pencapaian orientasi. Oleh karenanya motivasi dan belajar mempunyai peran yang saling mempengaruhi satu sama lain. Hal tersebut dikarenakan belajar merupakan suatu perubahan tingkah laku secara relatif permanen dan secara potensial terjadi sebagai hasil dari praktik atau penguatan (reinforced practice) yang dilandasi tujuan untuk mencapai tujuan tertentu [6]. Siswa yang berprestasi cenderung memiliki keingintahuan intelektual yang kuat dan bersemangat untuk belajar.

\section{c. Hipotesis Ketiga}

Hasil dari pengujian anava dua jalan pada ranah kognitif menunjukkan bahwa nilai Sig. $(0,789)>\alpha(0,05)$, dan hasil pengujian Kruskal-Wallis pada ranah afektif menunjukkan bahwa nilai Sig. $(0,057)>\alpha(0,05)$. Hal ini berarti bahwa baik pada ranah kognitif maupun afektif menunjukkan bahwa nilai Sig. $>\alpha$ $(0,05)$, maka $\mathrm{H}_{O A B}$ diterima dan $\mathrm{H}_{1 \mathrm{AB}}$ ditolak. Dapat disimpulkan bahwa tidak terdapat interaksi antara model pembelajaran kooperatif TGT disertai KR-Chart, TAl disertai KR-Chart dan konvensional dengan motivasi belajar siswa terhadap prestasi belajar ranah kognitif maupun afektif siswa pada pokok bahasan sistem koloid.

Tidak adanya interaksi antara model pembelajaran kooperatif TGT disertai KR-Chart, TAl disertai KR-Chart dan konvensional dengan motivasi belajar siswa terhadap prestasi belajar ranah kognitif maupun afektif siswa pada pokok bahasan sistem koloid menunjukkan bahwa tidak ada perbedaan efek antara siswa yang dikenai model pembelajaran tertentu dengan motivasi belajar terhadap prestasi belajar siswa. Apapun model pembelajaran yang diterapkan, baik TGT disertai KR-Chart, TAI disertai KR-Chart maupun konvensional, prestasi belajar siswa yang memiliki motivasi belajar tinggi lebih tinggi dari pada prestasi belajar siswa yang memiliki motivasi belajar sedang, dan lebih tinggi dari pada prestasi belajar siswa yang memiliki motivasi belajar rendah. Hal ini dikarenakan siswa yang memiliki motivasi belajar tinggi akan memiliki dorongan atau hasrat untuk mencoba memecahkan masalah untuk menjawab pertanyaan-pertanyaan yang diberikan. Oleh karena itu dalam menyelesaikan soal-soal mereka menjadi lebih bersemangat sehingga prestasi yang diperoleh memuaskan. Sedangkan siswa yang mempunyai motivasi belajar sedang dan rendah cenderung kurang begitu aktif dan sekedar memperhatikan saja. Bahkan, siswa yang mempunyai motivasi belajar rendah terkadang hanya diam saja.

\section{KESIMPULAN}

Berdasarkan hasil penelitian, dapat disimpulkan, 1) terdapat pengaruh penerapan model TGT disertai KR-Chart, TAI disertai KR-Chart, dan konvensional terhadap prestasi belajar kimia ranah kognitif tetapi tidak terdapat pengaruh pada prestasi belajar kimia ranah afektif; 2) terdapat pengaruh motivasi belajar siswa pada pembelajaran materi koloid terhadap prestasi belajar kimia; 3) tidak ada interaksi antara penerapan model TGT disertai KR-Chart, model TAI disertai KR-Chart, dan konvensional dengan motivasi belajar siswa pada pembelajaran materi koloid terhadap prestasi belajar kimia

\section{UCAPAN TERIMAKASIH}

Bapak Drs. Jaka Wismono, M.Pd., selaku kepala Sekolah SMA Negeri Kebakkramat Karanganyar yang telah memberikan izin kepada penulis untuk melaksanakan penelitian dan Bapak Kasirin S.Pd., M.Pd., selaku guru mata pelajaran kimia kelas XI SMA Negeri Kebakkramat Karanganyar yang telah 
memberikan izin kepada penulis untuk melaksanakan penelitian pada kelas yang diampu.

\section{DAFTAR RUJUKAN}

[1] Mulyasa, (2014).Pengembangan dan Implementasi Kurikulim 2013. Bandung: PT.Remaja Rosdakarya.

[2] Syah, M. (2009). Psikologi Belajar. Jakarta : PT Raja Grafindo Persada.

[3] Slavin, R.E. (2010). Cooperative Learning Teori, Riset dan Praktik. Bandung:Nusa Media.

[4] Nurhayati, Sri., Mahatmanti, F W., Khodijah, F D. (2009). "Keefektifan Pembelajaran Berbasis Question Student Have dengan Bantuan Chemo-Edutainment Media Key Relation Chart Terhadap Hasil Belajar Siswa". Inovasi Pendidikan Kimia, 3 (1), 379-384.
[5] Rybczynski, Stephen M. and Schussler, Elisabeth E. (2013) "Effects of Instructional Model on Student Attitude in an Introductory Biology Laboratory," International Journal for the Scholarship of Teaching and Learning, 7 (2), Article 22.

[6] Uno, H.B. (2012). Teori Motivasi dan Pengukurannya. Jakarta : Bumi Aksara. 